\title{
6
}

\section{The Missionary's Dilemma: A Short History of Christian Marriage and its Impact upon Gender Equality in Maisin Society}

\author{
John Barker
}

Martha Macintyre opened 'Better homes and gardens' with a description of contemporary Tubetube houses. 'These houses,' she observed, 'being made entirely from "bush materials", conform to Western notions of the primitive or traditional architecture appropriate to a small tropical island' (1989, p. 156). Tubetube people, however, attributed the houses to Islander teachers who served as the workforce of the Methodist mission that arrived on the island in 1892. Drawing upon oral histories and archival sources, Macintyre related how the teachers focused their evangelical campaign against the houses of chiefs, due to the presence of ancestral skulls and other items they reasonably presumed to be associated with 'heathen' spiritual beliefs, warfare and sorcery. The destruction of the houses corresponded to the undermining of chiefly authority that, along with severe population loss through disease, ramified over time, ending Tubetube's involvement in regional trade networks and changing local patterns of settlement. Having helped to destroy the old society, the teachers provided new models of houses, gardens and ritual activities, now centred around the church. Macintyre concluded: 'when we are confronted by a church-going 
community in Papua New Guinea [PNG] it is easy to assume that the adoption of Christianity is an accretion'. A careful comparison of past and present forms and practices, however, reveals 'underlying ramifications of enforced change' (Macintyre, 1989, p. 169).

Macintyre's description of Tubetube villages could equally be applied to the Maisin of southern Collingwood Bay on the eastern edge of Oro Province. Visitors, including Maisin who have settled in towns, frequently praise the beauty of the bush-material houses, outrigger canoes lining the shores and subsistence gardens as evidence of traditional continuity, ignoring the abundant evidence of a connection to the outside world. When my wife, Anne Marie Tiejten, and I began our fieldwork in November 1981, we were aware that the Maisin had abandoned their traditional house forms for a type of bush house promoted by the former colonial administration. Yet we had been told, by the Archbishop of the PNG Anglican Church no less, that the Maisin were the most determinately 'traditional' of the coastal people within the Anglican fold. Indeed, it seemed the case that the Maisin and Anglican missionaries had found a comfortable balance between Christianity and tradition, one based upon distinguishing between the two as existing in separate physical and action spheres. Villagers worshipped and sent their children to school on a demarcated mission station while also conducting mortuary rituals and other traditional ceremonies in the surrounding villages (Barker, 1990).

Marriage appeared as the chief exception to this happy arrangement. I knew from the archival documents I had consulted in Port Moresby that the missionaries had waged a long war to bring the marriage practices of converts into conformance with church standards. The Papua New Guinean priest in charge of the St Thomas parish, based at Uiaku village, identified marriage and divorce as the major challenges he faced. When conducting a village census, I learned that very few people bothered with church weddings. Members of the church council and Mothers' Union spoke to me of their frustrations in encouraging villagers to conform to church rules on marriage and their inability to break up polygamous unions, of which there were five in the village at the time. Such problems did not seem to trouble most villagers, including those under discipline for remarriage, with young children who had to wait until adulthood to seek baptism. Couples who were legally married in the eyes of the church told me freely of their youthful sexual adventures and tolerated the same behaviour on the part of their unmarried children. The stability 
of marriage depended upon seemingly traditional norms: the production of children and maintenance of balanced exchange relationships between the patriclans joined by marriage.

Yet, as with the 'traditional' houses on Tubetube, appearances can be deceiving. Marriage, in addition to attitudes on gender, has changed over the decades, as much due to economic circumstances as direct challenges by Christian or secular evangelists. Further, while they might resist overt pressure to change their ways, most Maisin would agree in principle that marriages should conform to church rules and that women and men should have complementary, if not necessarily equivalent, statuses.

In this chapter, I explore the history and local ramifications of the Anglican campaign to impose Christian standards of marriage upon the Maisin, as they appeared in the 1980s. I set the stage by relating my first impressions of Maisin marriage and then drawing out the distinctions between indigenous and missionary assumptions about marriage and divorce. The next two sections draw upon archival sources and oral testimonies to outline the missionary push to impose Christian standards and the shape of the Maisin response. In the final ethnographic section, I examine the influences the missionary campaign had upon local understandings of gender, focusing on the experience of the local church women's group, the Mothers' Union. In the conclusion, I briefly discuss more recent changes in Maisin marriage practices in terms of their relationship to gender equality.

\section{A Maisin Wedding}

The Anglican mission was run by high churchmen who prided themselves on their sympathetic appreciation of indigenous Papuan culture. They aimed to instil a form of village Christianity that merged seamlessly with the values of strong family ties and simple spiritual faith that they imagined characterised indigenous life at its best. While this view satisfied their theological principles, it also had a pragmatic basis. The mission was extremely poor, in terms of both financial support and staffing. White missionaries lived in not-so-splendid isolation in charge of large districts, relying upon staffs of poorly educated Melanesian teachers who were initially recruited from the Queensland sugar fields to provide the bulk of teaching and preaching at the village level. White and brown mission staff depended heavily upon local people for food and labour. 
Consequently, campaigns against 'heathen' practices tended to be selective and vulnerable to local resistance. Missionaries spoke out against customs they considered harmful or offensive to Christian morality but did not require baptised villagers to separate themselves from their 'pagan' neighbours. In principle, Christians were held to a higher standard than unbaptised villagers, expected to regularly attend church services, to send their children to school and to observe church regulations in general (Wetherell, 1977). In practice, the missionaries' tolerance for indigenous culture amounted to a benign indifference to the contradictions between their own worldviews and those of their charges. ${ }^{1}$ The assumption that Christianity could be grafted onto native society allowed the missionaries to focus their energies on rules rather than reform. Therefore, the school day was thoroughly regulated, with students punished for the smallest infractions of teachers' authority. Further, full membership of the church was reserved for those who met its sacramental requirements, including baptism, confirmation and respect of Christian marriage vows. Outside this sphere, Christians continued to participate in customary activities, including initiation ceremonies, traditional dancing and death ceremonies-albeit with some restrictions, depending on the nature of the ceremonies and attitudes of particular missionaries (Barker, 1987).

I chose Uiaku for my research base because I wished to obtain a sense of the long-term ramifications of the Anglican project. The mission had established a church and school there in 1902. Apart from 1917-20, during which time a white priest briefly resided in Uiaku, all the teachers and clergy had been Papuans or other Melanesians. When we arrived in 1982, the Anglican Church was about to celebrate its first decade of independence and most Maisin were at least second-generation Christians. Therefore, Uiaku seemed perfect for my purposes. No aspect of indigenous life occupied the missionaries more than marriage. The mission logbooks from Uiaku and the district base at Wanigela were replete with entries recording efforts by the district missionaries and visiting bishops to educate newly baptised Christians about the church's expectations and

1 There were exceptions, notably the Reverend James Fisher, who described himself as the 'warden of the coast' as he launched a vigorous campaign to stamp out a range of local customs such as female facial tattooing and all-night dancing. However, Fisher's campaign of moral reform soon faltered, particularly beyond the head station at Wanigela. Like his contemporary, the Reverend Jennings at Uiaku, he suffered a breakdown and left the mission in 1923 (Barker, 1987; Fisher, 1915). 
interventions to break up marriages that were illegitimate in the eyes of the church. I was very interested in learning about marriage practices as a way of gauging the impact of the missionary practice of targeted intervention.

Prior to departing from Canada, I had received a letter from Sister Helen Roberts, a nurse-missionary who was based at Wanigela at the old mission regional headquarters and airstrip. She wrote that we would be most welcome at Uiaku, but that people would be very concerned about whether we had been 'properly' married in a church (we had). Upon arrival in Uiaku, however, nobody seemed interested in our legal marital status; instead, local people came up with a plan to seal our marriage with a customary wedding. Anne and I were promptly adopted by two clans, and, within days, I received a lesson on my obligations to in-laws (mainly plentiful gifts of tobacco and rice). A couple of months later, our romantic notion of Maisin traditions collided with reality. We were thrilled to be invited to a 'traditional' wedding at a small Maisin village to the east. Over the next four days, we sat on a shelter feeling increasingly bored, sweaty, dirty and itchy. Occasionally, an English speaker would pop by to check on us and to assure us that things were about to begin. Sometimes they did, for a short time, followed by long, tedious hours of waiting. It did not help that, after midnight, the local string band plugged a cheap guitar into a scratchy radio amplifier, serenading the assembled in loud falsetto harmony until dawn. I later learned that the action was taking place backstage in earnest negotiations to deal with various slights that threatened to upend the festivities. Thus, Anne and I were introduced to the rather improvised nature of Maisin customary rituals.

Therefore, it did not come as a total surprise to learn that customary wedding ceremonies were exceedingly rare, and church weddings were rarer still. We were relieved when talk of staging such an event for us quietly died down. People were very clear about what was supposed to happen. The delays and general confusion resulted from disagreements (and no doubt some posturing) regarding whether each of the participants had met their obligations and/or shown proper 'respect' to the other side. Given these challenges, most people acknowledged a marriage through a series of private exchanges of food between the extended families involved. Yet even in these cases, reaching a stable state of marriage proved to be anything but simple for many couples. I recorded many marriage narratives of byzantine complexity; tales of intrigue as clan leaders attempted to arrange advantageous marriages; forceful interventions when 
careful plans went array, sometimes leading to violence; elopements by starstruck lovers disowned by their disappointed parents; whispers of love magic, sorcery and abduction and more.

None of this seemed to have much to do with Christianity. Yet Maisin insisted that the mission had a distinct and necessary role to play. Marriages must be sanctioned by the church, people told me, if they were to be stable and the children baptised. Polygamous unions must be firmly opposed as exploitative, disruptive and, above all, un-Christian. However, each of these principles was compromised in practice. Most couples waited until one or more children had been born and their union felt stable before approaching the priest for a marriage blessing. At the time of my initial fieldwork, five households of the 90 or so in the village were polygamous.

Given first impressions, it would be easy to dismiss the Maisin's acceptance of Christian marriage as superficial, a case of 'Sunday Christians, Monday sorcerers', as an anthropologist working up the coast described local adjustments to mission introductions at this time (Kahn, 1983). The colonial missionaries had often described Maisin as 'recalcitrant' and would almost certainly regard the present-day situation as less of a compromise and more of a failure. Anthropologists might well be tempted to view the case of Maisin marriages as one of cultural continuity in change. Superficial changes in attitudes and practices may occur, but, for the most part, marriage practices conform to the exchange logic that permeates Maisin social action and thought (Barker, 2016). Yet, as I will demonstrate in the remainder of this chapter, the Maisin perception that Christianity is central to local marriage must be taken seriously. The Anglican campaign against customary marriage had a major impact on Maisin society, one that only becomes visible when we consider the wider ramifications of that project alongside the specific influences on marriage.

\section{Marriage Principles}

It was inevitable that missionaries and Maisin would clash over marriage because basic values were at stake. Marriage for Maisin exemplifies marawa-wawe - literally, the sharing of one's inner self with another-best translated as social amity based upon the balance between the exchange partners. Social amity as a perfect balance, however, is difficult to attain. In the past, Maisin favoured sister-exchanges (daati), often betrothing sons and daughters while they were very young. The frequency of such 
arrangements remains an open question-I recorded only one instance of a successful sister exchange among living Maisin. Older folk recalled two earlier instances, mostly because violence broke out after one of the engaged individuals broke the arrangement by eloping with someone else. Many older Maisin told me of being betrothed when entering their teens for a period of months or years, during which they were called 'husband' and 'wife' while working for their future in-laws, but often the children had other ideas and the engagement would be called off.

Marriage was and continues to be marked by exchanges of food and sometimes material items between the couple's families. One should marry outside one's patriclan and 'blood kin'-roughly figured as descendants of common grandparents. Normally, the women moved to the husband's residence. Maisin strongly preferred their daughters to marry into nearby families-not only for access to her labour but also to use rights to her husband's garden lands. In particular, the new husband marked his debt to his in-laws by providing regular small gifts of food and betelnut, assisting in gardening and other tasks and avoiding the use of their names. Such continuous informal exchanges prepared the ground for formal ceremonial prestations involving extended families. The husband's family reciprocated for the wife and her children either by fostering a child or providing a large bridewealth gift. In return, the wife's brothers organised the initiation of her first-born child. The cycle ended with the death of one or other of the married couple. The affines acquired the property of the survivor and, in return, took responsibility for overseeing their mourning, ending with a ceremony in which the widow or widower was decorated like a young person and released from their obligations to their in-laws (Barker, 2016; Hermkens, 2013).

These general principles permitted a wide variety of variations, depending on contingencies and the personalities involved. No doubt, marawa-wawe was less often achieved than referenced as a measure against which the actualities were measured. The point I wish to make here is that, as in other Melanesian societies, Maisin marriage ideals were firmly grounded in principles of reciprocal exchange.

The contrast with Anglican principles could hardly be greater. Adhering to Catholic teaching, the missionaries regarded Christian marriage as an institution ordained by God, one of seven Sacraments that were legally and spiritually binding upon Christians and regarding which no compromise could be allowed. As with baptism or participation in the Eucharist, 
marriage entailed a lifelong commitment not simply to one's partner but to the church itself. Christian marriage could only be formalised by an ordained priest, preferably in a church ceremony, but minimally with a blessing. Once properly married, the Christian was bound until death to his or her spouse. Divorce was not permitted and a Christian who left his or her spouse was subject to escalating discipline from the church (up to excommunication) unless the marriage was restored or the 'ring' spouse died.

Unlike their contemporaries in Protestant missions, the Anglicans, for the most part, did not justify their insistence on church-regulated marriage in terms of a larger project of regulating the behaviour of men and women within a sanctified Christian family (Jolly \& Macintyre, 1989). One finds little rhetoric in Anglican writings that condemns the supposed degraded status of women in native society or the exaltation of Christian domesticity in converts' lives. Instead, they focused their efforts on the reformation of the person, particularly males. The Papuan's 'special weaknesses, from a Christian point of view', observed the first Bishop of the mission, 'are impurity, untruthfulness and a callousness in giving pain, especially to dumb animals' (Stone-Wigg, 1907). Stone-Wigg condemned the 'utter laxity' with which men carried on their affairs with women both before and after marriage. The Papuan's propensity for lying, however, suggested a modicum of guilt upon which the missionaries could work. The first step was to ensure that converts complied with the marriage rule.

In sum, the Anglican position on marriage was grounded in the Christian individual's obligation to obey the dictates of God as represented in the Sacraments. Customary practices complicated missionary efforts to impose Christian marriage. Parents, one missionary complained, arranged marriages 'with an eye more upon the payment made, than upon a girl's wishes. This leads to unhappiness, desertion, and later, perhaps, excommunication' (Somerville, 1945, p. 163). Yet, in principle, native customs, including betrothals, could be squared with the sacramental requirements of the church. The missionary's job was to enforce the rules on their unruly 'children'. If they could be made to respect their marriage vows, converts would themselves reform customary practices as needed. 


\section{Disciplining Marriage}

In 1917, Bishop Gerald Sharp published a 36-page set of guidelines for priests in the New Guinea diocese that listed expectations, rules, procedures and resources. He devoted the longest sections to marriage, systematically laying out various permutations of acceptable and unacceptable unions, requirements for the marriage ceremony and forms of discipline to be applied to individuals and couples living 'in sin'. The Bishop found such detail necessary because 'lack of recognition of the marriage bond on the part of the natives has led to much difficulty, complication, and disappointment' (Sharp, 1917, p. 17). Ideally, an engaged Christian couple would have their banns read over the course of three weeks in the church before being married in a full Eucharist service by the district priest. The Bishop sorted through numerous complications arising from the fact that many of the first generation of baptised Papuans were already married or betrothed to pagans, setting out guidelines for distinguishing between 'legitimate' pagan marriage (which should continue) and 'concubinage' (which should not), the recognition of the 'true' wife or husband in cases of serial monogamy and the treatment of multiple wives in polygamous marriages.

'Fortunately', the Bishop declared, 'we live in a country in which ecclesiastical discipline can be, and is, exercised' (Sharp, 1917, p. 14). He also stated that:

Those living in a state of mortal sin, who have, that is to say, arranged their lives so that they are, for the time, being lived in a manner directly opposed to the plain meaning of the 7th Commandment, ${ }^{2}$ must be excluded from all Christian services until they set right their lives. (1917, p. 14)

'Setting right' their lives should begin by asking permission and then faithfully attending Matins and Evensong services, sitting with catechumens in Sunday services and leaving following the recitation of the Nicene Creed. If they persist in sin, the Bishop had no option but to excommunicate:

2 The commandment that forbids adultery. 
An excommunicated person should not be allowed to go on the mission station for any purpose whatever, except to enquire about his own restoration from the priest or the Bishop. He must not bring or send any food to the missionary for sale; and if he dies excommunicate, he cannot be buried with a service, nor in the Christian cemetery. His own people must bury him in their own way. (Sharp, 1917, p. 15)

Bishop Sharp concluded his list of prohibitions with instructions that missionaries should encourage all baptised Christians to shun the miscreant.

Some years passed between the establishment of the first mission station among the Maisin and the enforcement of marriage rules (Barker, 2005b). In 1902, an Australian lay missionary, Percy John Money, supervised the construction of a massive mission station at Uiaku, with a church capable of serving the entire population of approximately 500 souls. The mission, however, was unable to appoint a white missionary, and progress under a handful of resident Melanesian teachers was slow. In 1914, a newly arrived district missionary based at Wanigela (to the north of the Maisin territory) made Uiaku his special project, visiting the village weekly to prepare a catechumen class for baptism. Three years later, roughly 170 Maisin had become Christians, prompting the mission to turn the Maisin villages into a parish and assign the Reverend A. P. Jennings as its district priest.

Jennings did his best to enforce church authority, particularly with the adolescent boys and girls boarded under his charge on the mission station. Within a few months of his arrival, he was directing the flogging of schoolboys for 'fortification' and, in one incident recalled by Maisin elders more than 60 years later, suspended six girls from communion and ordered their heads shaved and ornaments removed. He records only one intervention in a marriage in the Uiaku logbook, writing of having recruited a government policeman to bring back a schoolgirl who had eloped with an older man who already had two wives. This may have reflected caution as much as need; following Jennings' disciplinary actions, he often had to send his boarders home after their parents refused to provide food for them. The isolation, bouts of malaria and intransigent parishioners steadily wore Jennings down, but it was drumming that eventually ended his short residence. A lover of classical music, the priest could barely abide the steady beat of drums accompanied by the rise and fall of chanting-it is also that Jennings suspected that young 
people found the greatest opportunities for sexual dalliances during such occasions. Initially, Maisin respected his requests to cease dancing before midnight, so that school children would not arrive exhausted the next day, but this did not last. The last straw occurred in 1920. In response to what the district missionary at Wanigela described as a 'strange snake cult' (to which I will return later), the people of Uiaku took up their drums and feathers, dancing dusk to dawn over the course of weeks. Close to a mental breakdown, Jennings fled.

St Thomas Parish in the Maisin villages continued to be staffed by Melanesian and, later, Papua teacher-evangelists who provided instruction in the schools and non-communal Sunday services. Unlike their Polynesian and Fijian counterparts in the Methodist and Congregationalist missions elsewhere in Papua, they did not aggressively seek to impose their notion of Christian morality upon villagers. Responsibility for instruction or discipline in 'proper' Christian behaviour in Uiaku now fell on the shoulders of the district missionary in Wanigela. Throughout the 1920s, one finds entries on the priest's and Bishop's attempts to enforce mission marriage laws on the Maisin. The following description is typical:

Edric Mamatu or Emanu married Gameti by native custom but the marriage was not acknowledged. He then took Gertrude sister of Waiko? Rarara \& Eric Tama who object to their sister being with Edric. If Edric wants Gameti \& will send away Gertrude [sic] marriage with Gameti will be acknowledged. If not Edric \& Gertrude will be excommunicated. (Wanigela Log Book, 28 November 1923)

The logbook does not provide a full or entirely reliable record of missionary interventions. The priest made only periodic visits to Uiaku for communion services; therefore, he relied mainly upon reports by teachers and members of the church council concerning sexual affairs and marriages. They were often uncertain of the names of unbaptised villagers and ignorant of the complex family negotiations surrounding marriages. To add to the unreliability, the degree of detail provided in the logbook waxed and waned over time, with some entries only listing numbers of excommunicates during one of the Bishop's visits or vague information regarding discipline. Still, there is enough information to indicate that the mission maintained its strict stance on marriage and divorce through succeeding decades. Eventually, there was some easing of enforcement, particularly once Papuan priests were appointed to the St Thomas Parish, beginning in 1962. The practice of excommunication effectively ended, 
and church marriages remained exceedingly rare. Most couples 'living in sin' in the eyes of the church sought restoration after the birth of one or two children. Divorced individuals who had remarried could remain under discipline, and their children were denied baptism until they reached adulthood at age 18 .

\section{Maisin Responses}

Regardless of their own personal exasperation, the district missionaries listed the disciplined and excommunicated in the logbook with a bureaucratic hand. Anglican propagandists took a different tack, favouring purple prose and a heavy-handed paternalism. Taken together, these two styles reveal much of the missionaries' assumptions about their project to enforce Christian marriage. In a near-perfect example of the genre, the Reverend James Benson tells the story of Foa, 'the fairest, sweetest and best of the three of Mandarena, who was the "taumanuma" (i.e., the high chief) of the Uiaku tribe' (Benson, 1923, p. 104). Foa had been betrothed as an infant to Urakueta in Bonando village. After taking Christian instruction, the newly baptised Winifred lets it be known that she wants no part of Urakueta, known to be 'in truth, a worthless scamp'. Urakueta's people stage a raid and steal Winifred, causing her relatives to gather their clubs and spears and attack Bonando. In the fracas, an Uiaku man is clubbed to death. Shocked by their actions, the Maisin fall into a 'sober stillness' as they await the arrival of the district priest. The latter quickly sorts things out, sending the warriors to Tufi to stand trial and arranging for Bonando to compensate Uiaku with shell moneythe customary payment for a homicide - on the neutral grounds of the Wanigela mission. When tensions flare up again, the missionary arranges a new home for Urakueta's kin at Wanigela. Winifred also settles at Wanigela, 'waiting for and looking for her true love, and he who wins her will win that which is more precious than all the jewels of a hundred Bonandos, for "a good wife is more precious than rubies"' (Benson, 1923, p. 104).

In this scenario, the missionaries regarded Maisin and other Papuans as childlike. They would only be brought to an understanding of the institution of Christian marriage through patient education and firm discipline. Maisin, however, did not regard marriage as an institution, but rather a locus formed by and around various exchanges. The information 
that may be gleaned through archival and oral sources strongly suggests that the fight over Winifred had little (if anything) to do with her Christian status. The entry in the Wanigela logbook reveals that Winifred's betrothed had also received baptism. The fight broke out when a senior man in Uiaku took Winifred as his second wife while her betrothed was away working on a distant planation. Therefore, the evidence indicates that the conflict was over a broken sister exchange.

I would suggest that, rather than seeing the mission as offering an alternative form of marriage, Maisin in the early years likely regarded the missionaries' actions as one complication among many that affected marriage negotiations at the time. Winifred's double removal-first to Bonando and then to the Wanigela station-occurred in the significant year of 1921. The previous year had seen the emergence in Uiaku of a 'snake cult' and the hurried departure of Jennings. This movement, an offspring of the so-called Baigona cult of a decade earlier, focused on a crisis of rampant sorcery and death. Ten days after removing Winifred, the district missionary visited Uiaku and took down the names of ' 84 men reputed to be using lime pots for nefarious purposes' (Wanigela Log Book, 25 April 1921). A month later, he returned to supervise the public destruction of lime pots and the sharing of food to assure that any man fasting would lose his power. The clans in conflict over Winifred symbolically destroyed war clubs at the same gathering.

The causes of the panic cannot be known, although it is noteworthy that it occurred during the years of the worldwide influenza pandemic. Sickness placed a premium on children. At the time, the Resident Magistrate noted that 'several people have taken a second wife on the plea that the first has not borne any children' (Muscutt, 1921). Other factors also likely affected marriage negotiations. Labour-recruiting began around 1910, and the absence of young unmarried men increased opportunities for polygynous marriages, at least initially. Young labourers returned with goods purchased in eastern plantations, challenging the authority of older men. During this same period, the resident magistrates and police had been putting increasing pressure on Maisin to rebuild their villages, plant coconut plantations to earn money from selling copra and serve as carriers on patrol. In 1918, the government further strengthened its hand by imposing a head tax on adult males, to be paid off either in cash or labour in the new village plantations. This provided an inducement to form larger families, as did the government's new policy of providing five shilling per annum bonuses for young children, a response to the crisis 
of rapidly declining populations in parts of the Territory. In this context, the case of Winifred's abduction appears as much more than a simple story of a contest between indigenous and Christian forms of marriage.

Such complexities must be kept in mind when reviewing the mission's campaign to establish Christian marriage during the colonial period. The logbook entries listing marriages, individuals under discipline and excommunications imply a one-sided battle that eventually sputtered and failed. There are clues, however, that Maisin drew the mission into local marriage negotiations. Early in 1925, for instance, the district missionary was approached by an unbaptised young couple who requested him to marry them 'thinking thereby to avoid the necessity of doing so in the villages where the subject was unpopular'. He sent them away, only to be visited by the girl's brother who asked if the mission would give permission for the girl to be returned to her mother: 'He too was told that he and the parties concerned must settle the matter themselves as it is not the practice of the missionaries to interfere in the affairs of heathen people' (Wanigela Log Book, 27 Jan. 1925). Evidently, some Maisin had come to accept the mission's participation in marriage negotiations, even if they did not necessarily understand the conception of marriage they worked to impose.

In the early 1980s, I interviewed several elders (who had come of age in the early 1920s) about their experience of the mission and their own Christian beliefs. They listed various things that missionaries opposed, including polygyny, but limited their positive contributions to two: the rudimentary education provided at the school and the bringing of peace. No one suggested that the mission had introduced a new conception of marriage, although a handful of people had been married in church (and some since divorced and placed under discipline for varying periods). Instead, when I introduced the subject of marriage and the mission, conversation inevitably turned to instances where the missionaries, church councillors or the Mothers' Union had intervened to separate a young couple or to prevent a polygynous union. People sometimes mentioned church law, but for the most part, they justified these interventions as preventing fights. One woman related a complex story of several young people who eloped with someone other than their betrothed. The Bishop came to the village and publicly destroyed a tapa cloth bearing the clan emblem of one of the parents to signify the end of the practice of child 
betrothals. 'There had been so much fighting,' she told me, 'that people were pleased when this law came in' (Interview with Ida Elsie Aibu, Uiaku village, 9 March 1983).

The elders' reference to 'peace' is significant. While missionaries did occasionally portray themselves as peacemakers, they placed far less emphasis on conversion as a dramatic movement 'from darkness to light' than Protestant missions elsewhere in Papua and New Guinea. The idiom of peace-making resonates more with indigenous conceptions of asymmetrical reciprocity (in general) and leadership (in particular). Maisin distinguish between two types of clans, with respective leaders (Barker, 2005a). The higher-ranked kawo have the prerogative of hosting feasts on the plaza before their houses, in addition to speaking first at gatherings. The kawo build alliances and, thus, make peace. They are assisted by lower ranked sabu, who provide food and dance during ceremonies. They are said to be passionate warriors. Maisin liken the relationship between kawo and sabu as between elder and younger brothers. The kawo provide guidance for supposedly hot-headed $s a b u$, leading them in times of peace and unleashing them for war. In the 1980s, adult Maisin spoke of the clergy, teachers and missionaries of old in a similar fashion. Like kawo (or older siblings or wife-givers), the church gave villagers something of greater value than they received in turn-knowledge and blessings of the Christian God. In return, like sabu (or younger siblings or wife-receivers), the villagers owed them 'respect' (muan). 'Peace' (sinan), on which health, integrity and material success ultimately rely, depended in turn on bringing the mutual gifts offered by mission and village into balance, a state of social amity (marawa-wawe).

The attainment of social amity is also central to the Maisin conception of marriage, yet it is difficult to obtain. The most common frictions in Maisin society occur across the marriage line-these frequently cause accusations of sorcery. The involvement of the mission in local marriage arrangements added a complication that villagers no doubt found inconvenient, mystifying or annoying, depending on the circumstances. Yet this same involvement may be useful when marriage arrangements come unglued and tempers threaten to get out of hand. While the practice of infant betrothal does not appear to have been vanquished by the single act of a bishop, it did decline after Christian conversion and was abandoned by the early 1950s. 
Over the decades, the mission's campaign to regulate Christian marriage among the Maisin also waned. Although divorce continued to be a problem for the church, the national priests who replaced the missionaries proved reluctant to intervene with young couples 'living in sin'. In a quiet compromise, priests and couples alike tended to wait until children had been born and a marriage appeared stable before conducting a brief blessing ceremony. Bishop Sharp's notion of Christian marriage would remain an ideal for most Maisin. Yet the intervention was not without profound effects. It added to the changes that were diminishing the power of male leaders, which had already been weakened by the forceful ending of warfare and young men's acquisition of new forms of wealth on the plantations. It also increased the ability of young adults to resist and foil their elders' marriage schemes. More subtly, it created a dilemma for more devout Maisin, who now had to come to seek balanced moral relationships not just with their affines, but with their church and God.

I gained a sense of this dilemma from several of the stories people told me of their marriages. Cuthbert, a man in his mid-70s in 1983, had been through short-lived marriages, one with the 'ring wife' of another man, before settling down with Linda. Linda's first marriage had been church-blessed, but her husband abandoned her to join the Papuan Constabulary. She had entered two succeeding unions, only to be rejected when no children were forthcoming. The district missionary and Bishop urged Cuthbert to send Linda away, but he refused. The couple was placed under discipline and denied entry to the church and the mission station. Many years passed and Cuthbert had a dream: 'I saw the church leaders sitting down. They asked, "Who are you?" And I asked, "Where is God?" They replied, "You can't see God and neither can we". 'This occurred on Good Friday. The following December, Cuthbert and Linda brought fish and taro to the annual patronal celebration on the station. They continued to do this every year, although they did not attend church services.

Cuthbert explained to me that marrying Linda had been 'my first mistake and I don't want to have two or three mistakes'. 'Mistakes' (daa), in Maisin parlance, refer to breaches in reciprocal relationships that invite retaliation. Cuthbert did not blame the church for punishing him and Linda, but it still brought sadness and shame. His dream suggested that the breached relationship had harmed both parties-neither could see God. His and Linda's act of reconciliation marked a movement to restore the bond. The missionary's dilemma remained-Cuthbert and Linda still 
'lived in sin'. Yet for Cuthbert, who wept as he told me his story, the weight of separation had been lifted, at least in part. The gathered had happily accepted his gifts at the St Thomas Day celebration, Linda had joined the women cooking the food for the communal feast and he had taken his place among the kawo elders garbed in traditional dress, to enjoy the traditional dancing and festivities.

While moving towards reconciliation, Cuthbert and Linda's actions could not overcome the church's strict prohibition on divorce. They remained on the list of former congregants banned from receiving communion. By the 1980s, concerns about reconciling Christian and indigenous marriage commitments were beginning to be overtaken by a fear that many young people were avoiding both. Many young people had taken advantage of the opportunities provided by both the mission and the government for advanced education in the post-War period and resettled in urban areas as they took up employment during the late colonial and early independence periods. Even as they lost some control over their migrant children, the ageing population in the Maisin villages scolded remaining 'school-leavers' for being self-willed in their sexual activities and choices of partners. As evidence, they pointed to the growing numbers of unmarried pregnant girls. In condemning this supposed trend, the clergy and villagers united in 'cleaning up' after sexual liaisons resulted in births, by forcing couples into marriage (although not always with the biological fathers). The 'traditional' wedding that Anne and I attended in the early months of our fieldwork originated as an effort to impose control over such an unsanctioned union.

\section{Reconfiguring Gender Relations}

The Anglican campaign to impose Christian marriage had wider implications for gender relations in Maisin society. In his seminal essay, 'Missionary occasions', Burridge wrote that 'the missionary's dilemma, which cannot be escaped, focuses on the crucial institution of marriage'. Christian marriage, he continued, 'connotes ideally the union in love of initially equivalent souls each of which finds salvation in the love of God, each other, and others' - that is, an ontological equivalence between women and men before God. Further, he explained 'that equivalent ontological status, whatever the imperfections of the transient social order, is all-important' (Burridge, 1978, p. 23). This principle lies at the 
heart of Christianity as a metacultural phenomenon; it creates endless problems for missionary and convert alike, because it is entirely unclear how or if any particular social order could live up to this ideal.

Protestant and Catholic missions operating in Papua approached gender in distinctive ways that reflect underlying theological and institutional differences. The London Missionary Society and Methodist missions in Papua built their local organisations around married couples. Whether a white couple in a head station or Islander teacher and his wife in a village, the missionary ideally modelled a 'civilised Christian home' (Langmore, 1989). Larger 'industrial' mission stations, such as Kwato near Samarai, provided men and women with training in their respective domestic skills, such as boat building for men and sewing for women, although their ability to enforce conformance to middle-class European norms (on which they modelled the family) tended to be limited to converts recruited to themselves become evangelists (Wetherell, 1996). The emphasis in the Roman Catholic and Anglo-Catholic missions, in contrast, was on 'the community, the total mission family' (Langmore, 1989, p. 82). They sought to impose a hierarchical Christian order, loosely based on a romantic notion of the medieval church, in which the local priest served as the 'father' over his parish, under the bishop and under God. Ideally, if not entirely in practice, the Anglican missionary was a celibate. Equally importantly, the focus of mission life was less on the family than on adherence to the daily round of worship and communal sharing. Whereas the better endowed Protestant missionaries hired servants to work in their households, Anglicans made a virtue of relying on the generosity of local villagers. Through vocation as much as necessity, they were prone to tolerate (or conveniently ignore) local behaviours that would have offended many of their Protestant colleagues_-as long as the essentials of Christian membership were respected.

Such differences help to explain why Anglican missionaries focused narrowly on enforcing marriage vows, rather than undertaking a more ambitious project of reforming the family or gender relations. This is not to suggest, however, that the mission's intrusions were without effect. With the important exception of church offices, the Sacraments did not distinguish between males and females. From the beginning, girls and boys attended school and church together. They shared the experience of baptism, received Christian names, were confirmed as members of the church by visiting bishops, and were served the eucharistic host by district priests. Females and males sat in segregated areas in the classroom 
and church, but this shared experience still suggested a certain type of equivalency that was contrary to the indigenous social order that sharply differentiated the genders, both in their working roles and physical substance. Only males could advance to church leadership, but women assumed responsibility for preparing the church for worship, for gathering and cooking food for Christian festivals, and so forth. I have found no evidence that Maisin considered the church a feminine domain, as Ericksen suggested for Presbyterians on Ambrym in Vanuatu (Eriksen, 2008); nevertheless, it provided a space in which Christian women could gather, work together, gossip and joke away from the purview of brothers, fathers and mothers-in-law.

Ultimately, however, the mission had its most direct impact on Maisin gender relations through its long-running efforts to enforce its marriage rules by recruiting converts in good standing to the cause. In 1920, Jennings formed a church council whose main task was to assure compliance with church rules, especially marriage. The council, which comprised males who represented different hamlets in the village, does not appear to have been very active. A significant shift in the church's relationship with the Maisin began in the late 1940s, in the aftermath of World War II, in which Maisin had served as carriers for the Australian army in the Kokoda-Buna campaign. Inspired by the creation of a village cooperative at Gona under the supervision of an Anglican missionary, the Maisin, in addition to many others in the Northern District, began their own Christian cooperatives, starting plantations of coconuts and cacao in hopes of generating funds for local economic development. Initially encouraged by the mission, these efforts had a strong spiritual overtone that concerned local government officers, who were worried about 'cargoism' (Barker, 1996). These were entirely male endeavours, but during the same period, the mission began introducing chapters of the Mothers' Union at some of its district stations, under the supervision of female lay missionaries.

Maisin women took notice of this. By 1948, a small group of younger Christian women, who were in good standing with the church, had organised a chapter in Uiaku-others soon followed in the rest of the Maisin villages. Missionaries regarded the Mothers' Union as an auxiliary organisation. In addition to assisting women in their spiritual lives and during times of sickness, the Mothers were expected to assist the local clergy, particularly in cleaning the church for services, and help the all-male church council to enforce church discipline. The pioneers who formed the 
Uiaku Mothers' Union saw it as something greater than this, associating the creation of the Union with the liberation of women from customs such as the shearing of a new wife's hair upon marriage and self-laceration at the time of deaths. They spoke of energetic intervention to prevent men from taking on multiple wives. They also took great pride in forming an organisation with officers and economic initiatives, specifically the sale of decorated tapa cloth through the mission, equivalent to those in the malerun cooperatives. As evidence of their success, they pointed to the sewing machines they had purchased from tapa sales in addition to their financial contribution to the building of the first iron-roofed church in 1962 and the mission's appointment of a Papuan priest to the St Thomas Parish.

In the early 1980s, the Mothers' Union appeared but a shell of its former self-small, with ageing members. But looks were deceiving. Its members included the most experienced artists in the traditional forms of tapa and facial tattoo design-women who enjoyed a steadier income than most-in addition to elders, who were knowledgeable in clan histories and traditional healing. On church festival days, particularly the annual Ladies Day, the Mothers proved adept at organising young women (including some under church discipline) to gather food, cook, serve and dance. Occasionally, during community meetings at which the senior men discussed economic development projects, the funding of the clergy or the unending failures of the village cooperatives, a Mother would stand up to remind the men that much of the funds came from their tapa sales - therefore, they needed to come up with their own ways of making money and not push the women so hard. The Mothers' Union came into its own during the late 1990s. The Maisin rejection of industrial logging attracted a wave of attention and support from international environmentalists and their allies (Barker, 2016). Tapa was immediately identified as a sustainable economic alternative to logging; consequently, sales increased enormously. Much of this sudden wealth was captured by men within houses and the political leadership. However, as happened elsewhere in the region, the non-governmental organisations took women's role in development as a key mandate and tended to regard women's voluntary organisations as more responsible with funds than men's. The Mothers' distinctive blue skirts became increasingly visible as the chapter expanded in membership; the Ladies Day celebration competed with the patronal feast day in size; the Union purchased its own dinghy, and its leaders regularly attended regional assemblies. Further, when the parish priest attempted to commandeer the dingy, the Mothers threatened to go on strike—he quickly backed down (Barker \& Hermkens, 2016). 
The Mothers' Union cannot be described as reformist, let alone radical, in terms of gender equality. Its views on marriage and the respective roles of men and women were extremely conservative. Rather than breaking with past gender relationships, the Mothers ratcheted up the already considerable authority of a mother-in-law over her sons' daughters and, to a lesser extent, the daughter-in-law's kin, who were obliged to offer her respect in the form of name avoidance and gifts of food, labour and wealth. In this way, the traditional ideal of marawa-wawe-a balanced exchange relationship—-became fused with the ideal of Christian marriage, a domain now dominated not by clergy but senior church women.

\section{Conclusion}

On the afternoon of 24 October 1982, people gathered on the Uiaku mission station to discuss the problem of disobedient young people, who had not 'respected' the church by attending services or, in the case of those whose parents were under discipline, seeking baptism on their own. The parish priest opened by venting his frustrations with both the youth and their families. He urged them to mend their ways, as one never knew what the future would hold. He noted the case of R, who had been church secretary when he arrived in St Thomas Parish but then took a second wife. ' $R$ ', the priest continued, 'still is a faithful man. He bears the burden of being cut off from the church. He didn't expect to be in this position. One day, he might go back to his wife [i.e., send away his second wife]. $\mathrm{He}$ is a good Christian man.' $\mathrm{R}$ sat quietly through this speech-in fact, $\mathrm{R}$ had called the meeting. The missionaries had long since departed, but the dilemma over marriage persisted.

In the distant past, the 'big men' in Maisin society commonly practised polygyny. Yet it would be as misleading to argue that R's marital status represented a traditionalist's rejection of Christianity as to assume that, due to the continued use of thatch and sago, the design of village houses remained untouched by change. Indeed, in one important respect, the missionary project enjoyed considerable success. Limiting themselves to enforcing sacramental marriage, the missionaries generally left Maisin to work out the implications for family and gender relations. Various adjustments and compromises ensued. The Papua New Guinean clergy who had replaced the foreign missionaries learned to turn a blind eye to the previous sexual and marital histories of couples whose marriages 
they blessed and children they baptised; thus, they preserved the ideal of church-sanctioned marriage. Villagers quietly abandoned child betrothals and sibling exchanges while continuing to articulate marriages through a series of lifelong exchanges between affinal kin. Finally, when conflicts arose, as they regularly did, over matters such as an 'improper' marriage or overly delayed bridewealth payment, some senior voices would appeal to the values of Christian fellowship or urge a gift to restore social balanceoften both-to maintain peace. This is not to suggest that peace could always be obtained. Breaches of ideals, real and imagined, fuelled nearconstant gossip, recriminations and rumours of sorcery. Christian marriage and balanced exchange were ideals that existed in tension not only with each other but also with the subjective perceptions of fellow villagers. They oriented behaviour and its evaluation but did not determine it.

Marriage provides a privileged location in which to assess gender relations. As Macintyre noted in a recent essay, the 'study of gender and sexuality in Melanesia has long been structured in terms of the theoretical concerns of anthropology as a discipline' (2019, p. 285). Such concerns have largely centred around questions of male domination of females, gendered agency and conceptions of the person and gender in indigenous Melanesian culture. However, even as debates waxed and waned within and between these concerns, historical and anthropological research has revealed how wider social, economic and religious changes have profoundly transformed the contexts in which people interact and perceive themselves ... The concomitant changes in gender relations have been profound and disruptive of earlier conceptualisations of male and female identity' (Macintyre, 2019, p. 288).

Through most of the twentieth century, the Anglican mission had the most direct impact upon Maisin gender relations, primarily through its campaign to impose sacramental marriage. At the time of my earlier fieldwork in the 1980s, the Maisin drew a sharp distinction between the 'village', 'government' and 'mission' spheres of social and political activities (Barker, 2007). This masked the degree to which the mission campaign ramified through society as a whole and affected not only the conception of marriage but also customary practices. Since this time, changes in gender ideologies and practices have become increasingly visible and profound. Several factors have contributed to this - the most immediate has been through engagement with international environmental activists, who (since the mid-1990s) have partnered with the Maisin to block industrial logging in their traditional territories, while also fostering 
alternate sustainable local development. Although vocally supportive of Maisin 'culture', many of these same activists are strongly committed to empowering women, whom they have insisted should serve in equal numbers on local committees (Barker, 2016). Over the long term, however, influences from beyond the villages have had a more lasting impact. Many Maisin have attended at least high school and, today, at least a quarter of those born in the villages now reside in urban areas, where many hold well-paying jobs. Many have married non-Maisin and/or left the Anglican Church for other denominations, exposing them to alternative traditions of gender and marriage. Although the villages are physically more isolated than in the late colonial and early postcolonial eras (due to the closing of local airstrips), considerable movement occurs between rural and urban areas. Maisin, particularly younger people, are increasingly exposed to representations of compassionate marriage in church sermons, television programs, commercial advertising and social media. Such representations are widely influencing young people's understandings of courtship, sexuality and marriage choice and mutuality (Cox \& Macintyre, 2014).

In Uiaku, as elsewhere, such changes disrupt the old certainties, prompting confusion, resentment and resistance, particularly (but not only) from older generations. As Ryan Schram aptly described, in terms of the Auhelawa people of nearby Duau (Normanby Island), the Maisin appear to have entered a 'post-cultural' era, in which all the received guidelines for behaviour appear to be up for negotiation (Schram, 2018). All the same, memories of custom and the notion of sacramental marriage will likely continue to be touchstones as Maisin adjust their expectations and practices of marriage. On our last visit to Uiaku in 2007, Anne and I met a woman who had left an abusive relationship in town to marry (village-style) an old sweetheart. The couple clearly regarded their marriage as a relationship built on mutuality, yet they submitted to the customary demands of their respective in-laws, adhered to the traditional division of labour in the garden and at home and expected to arrange a bridewealth exchange in the near future. Couples continued to avoid church marriage in favour of blessings after the birth of several children, but a simplified version of the 'traditional' wedding ceremony, like the one we had experienced in 1982, continued and had become more common. We learned that we had become exemplars of the tradition because it was universally believed that our adoptive clans had married us in the 'traditional' fashion when we first arrived in the village. 


\section{References}

Barker, J. (1987). Cheerful pragmatists: Anglican missionaries among the Maisin of Collingwood Bay, Northeastern Papua, 1898-1920. Journal of Pacific History, 22(2), 66-81. doi.org/10.1080/00223348708572553

Barker, J. (1990). Mission station and village: Cultural practice and representations in Maisin society. In J. Barker (Ed.), Christianity in Oceania: Ethnographic perspectives (pp. 173-196). Lanham, MD: University Press of America.

Barker, J. (1996). Village inventions: Historical variations upon a regional theme in Uiaku, Papua New Guinea. Oceania, 66(3), 211-219. doi.org/10.1002/ j.1834-4461.1996.tb02552.x

Barker, J. (2005a). Kawo and Sabu: Perceptions of traditional leadership among the Maisin of Papua New Guinea. In C. Gross, H. D. Lyons \& D. A. Counts (Eds), A polymath anthropologist: Essays in honour of Ann Chowning (pp. 131-137). Auckland, New Zealand: University of Auckland.

Barker, J. (2005b). An outpost in Papua: Anglican missionaries and Melanesian teachers among the Maisin, 1902-1934. In P. Brock (Ed.), Indigenous peoples and religious change (pp. 79-106). Leiden, Netherlands: Brill. doi.org/10.1163/ 9789047405559_006

Barker, J. (2007). Taking sides: The post-colonial triangle in Uiaku. In J. Barker (Ed.), The anthropology of morality in Melanesia and beyond (pp. 75-91). Aldershot, England: Ashgate.

Barker, J. (2016). Ancestral lines: The Maisin of Papua New Guinea and the fate of the rainforest (2nd ed.). Toronto, Canada: University of Toronto Press.

Barker, J. \& Hermkens, A.-K. (2016). The Mothers' Union goes on strike: Women, tapa cloth and Christianity in a Papua New Guinea society. The Journal of Anthropology, 27(2), 185-205. doi.org/10.1111/taja.12193

Benson, J. (1923). The crown jewels of Bonando. Australian Board of Missions Review, 15(6), 103-105.

Burridge, K. (1978). Introduction: Missionary occasions. In J. A. Boutilier, D. T. Hughes \& S. W. Tiffany (Eds), Mission, church and sect in Oceania (pp. 1-30). Lanham, MD: University Press of America.

Cox, J. \& Macintyre, M. (2014). Christian marriage, money scams and Melanesian social imaginaries. Oceania, 84(2), 138-157. doi.org/10.1002/ocea.5048

Eriksen, A. (2008). Gender, Christianity and change in Vanuatu. Aldershot, England: Ashgate. 
Fisher, J. E. J. (1915). The warden of the Coast. Australian Board of Missions Review, 6, 167-169.

Hermkens, A.-K. (2013). Engendering objects: Dynamics of barkcloth and gender among the Maisin of Papua New Guinea. Leiden, Netherlands: Sidestone Press.

Jolly, M. \& Macintyre, M. (Eds). (1989). Family and gender in the Pacific: Domestic contradictions and the colonial impact. Cambridge, England: Cambridge University Press.

Kahn, M. (1983). Sunday Christians, Monday sorcerers: Selective adaptation to missionisation in Wamira. Journal of Pacific History, 18(2), 96-112.

Langmore, D. (1989). Missionary lives: Papua, 1874-1914. Honolulu, HI: University of Hawai'i Press.

Macintyre, M. (1989). Better homes and gardens. In M. Jolly \& M. Macintyre (Eds), Family and gender in the Pacific (pp. 156-169). Cambridge, England: Cambridge University Press.

Macintyre, M. (2019). Gender relations and human rights in Melanesia. In E. Hirsch \& W. Rollason (Eds), The Melanesian world (pp. 285-299). London, England: Routledge. doi.org/10.4324/9781315529691-16

Muscutt, C. A. (1921). Patrol report to Collingwood Bay, 25 April-26 May. Cape Nelson Station, Box 6518. Port Moresby: National Archives of Papua New Guinea.

Schram, R. (2018). Harvests, feasts and graves: Postcultural consciousness in contemporary Papua New Guinea. Ithaca, NY: Cornell University Press. doi.org/ $10.7591 / 9781501711015$

Sharp, G. (1917). Diocese of New Guinea: Its rules and methods. Dogura.

Somerville, E. (1945). Our friends the Papuans. Sydney, NSW: Australian Board of Missions.

Stone-Wigg, J. M. (1907). The Papuans: A people of the South Pacific. In H. H. Montgomery (Ed.), Mankind and the Church. Retrieved from anglicanhistory.org/aus/hhmontgomery/mankind1907/stone-wigg01.html

Wanigela Log Book. (n.d.). Box 25, Anglican Archives, New Guinea Collection, Michael Somare Library, University of Papua New Guinea.

Wetherell, D. (1977). Reluctant mission: The Anglican Church in Papua New Guinea, 1891-1942. St Lucia, Qld: University of Queensland Press.

Wetherell, D. (1996). Charles Abel and the Kwato Mission of Papua New Guinea 1891-1975. Carlton South, Vic.: Melbourne University Press. 
This text is taken from Unequal Lives: Gender, Race and Class in the Western Pacific, edited by Nicholas A. Bainton, Debra McDougall, Kalissa Alexeyeff and John Cox, published 2021 by ANU Press, The Australian National University, Canberra, Australia.

doi.org/10.22459/UE.2020.06 